UDK 911.2:55](497.5)

$551.4(497.5)$

DOI 10.21861/HGG.2018.80.01.03

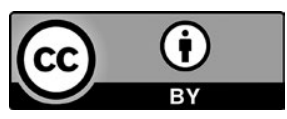

\title{
Models of geomorphometric parameters and drainage networks for the territory of Republic of Croatia
}

\author{
Modeli geomorfometrijskih parametara i drenažnih \\ mreža za prostor Republike Hrvałske
}

Models of geomorphometric parameters and drainage networks are widely used in many scientific and civilian branches and activities. They are created using the Earth's land surface data, which are today mostly represented by digital elevation models (DEMs).

The main objective of this study is to create models of slope, aspect, and drainage networks for the first time for the entire continental part of the Republic of Croatia, using the most detailed DEMs. In this paper, developed models are described, compared, and analysed, giving insights into morphological characteristics and structures of topographic surface. The quality of the derived models has been validated using existing independent data. Furthermore, because models were derived using various global DEMs, the differences between output models have been addressed and studied. Drainage network models were further analysed depending on several available computation algorithms (single and multiple flow direction) and threshold values. The analysis of the sensitivity and influence of input parameters and models on output models has been assessed in order to create reliable drainage network models for the future for other local or regional areas.

Key words: geomorphometric parameters, terrain slope, digital elevation models, drainage network, Croatia
Modeli geomorfometrijskih parametara i drenažne mreže imaju široku primjenu u mnogim znanstvenim i civilnim granama i aktivnostima. Izrađuju se iz podataka o Zemljinoj površini koji su najčešće objavljeni u obliku digitalnih modela reljefa (DMR).

Glavni je cilj ovoga rada izraditi modele nagiba, smjera nagiba i drenažnih mreža za kontinentalno područje Republike Hrvatske korištenjem najdetaljnijega globalnog digitalnog modela reljefa. Izrađeni modeli su opisani, uspoređeni i analizirani te daju uvid u morfološke oblike i strukture topografske površine. Kvaliteta modela provjerena je na postojećim neovisnim podacima. Osim toga, s obzirom na to da su modeli izrađeni korištenjem različitih globalnih digitalnih modela reljefa, analizirane su razlike između izlaznih modela. Modeli drenažne mreže dodatno su analizirani ovisno o korištenim algoritmima (jednosmjerni i višesmjerni protok) i graničnim vrijednostima. Analiza osjetljivosti i utjecaja ulaznih parametara i modela na izrađene modele bit će korisna za izradu pouzdanijih budućih modela drenažnih mreža za druga lokalna i regionalna područja.

Ključne riječi: geomorfološki parametri, nagib terena, digitalni modeli reljefa, drenažna mreža, Hrvatska 
HRVATSKI

GEOGRAFSKI

GLASNIK

80/1, 61-76 (2018.)

\section{Introduction}

Geomorphometry is scientific branch related to the quantitative land-surface analysis. It is an interdisciplinary branch that combines various mathematical, statistical, and image processing techniques, which can be used to quantify morphological, hydrological, ecological, and other aspects of land surface (Pahernik and Kereša, 2007; Pike et al., 2008). Geomorphometric analysis can be applied to particular types of landforms or to drainage basins (Sharma, 1981; Faivre, 2008).

Drainage networks and the associated channel links and drainage basins are fundamental concepts in Earth sciences. A drainage network is a network of channels and drains of all drainage basins of an area. Along with drainage channels, fluvial processes act to transport water and sediments out of a local region (O'Callaghan and Mark, 1984). The drainage basin is the area of land that drains water, sediments, and other materials towards a stream segment. Due to the widespread terminology, the term stream segment is used instead of the term network channel (USDA, 2010). Drainage basins connect to other drainage basins at lower elevations (Martz and Garbrecht, 1993; EEA Glossary, 2017; Monde Geospatial, 2017).

Geomorphologists analyse geomorphometric parameters, describe valley side and channel slopes, relief, drainage type, and other parameters. The geomorphometric analysis of a drainage network plays a significant role in understanding the geo-hydrological behaviour of drainage basins (Hajam, 2013). If drainage network models and geomorphometric parameters are combined, they can be used in predicting floods, modelling water flow, identifying and planning groundwater potential zones, and climate studies; as there are number of problems related to water from more frequent heavy rainfalls and massive floods (Chorowicz et al., 1992; Bognar and Faivre, 2006; Arumí et al., 2016). Also, they are useful for terrain visualization, spatial planning, civil engineering, hazard assessment (such as landslide prediction and mitigation), coastal protection, planning installations of lines of renewable and non-renewable energy sources and more (Martz and Garbrecht, 1992; Martz and Garbrecht, 1993; Soille and Gratin, 1994).

\section{Uvod}

Geomorfometrija je znanstvena grana koja se bavi kvantitativnom analizom površine terena. To je interdisciplinarna grana koja prikuplja različite matematičke, statističke i tehničke obrade slike koje se mogu koristiti za kvantificiranje morfoloških, hidroloških, ekoloških i drugih karakteristika Zemljine površine (Pahernik i Kereša, 2007; Pike i dr., 2008). Geomorfometrijske analize mogu se primijeniti na određeni tip zemljišta ili na drenažne bazene (Sharma, 1981; Faivre, 2008).

Drenažne mreže i drenažni bazeni temeljni su pojmovi u geoznanostima. Drenažna mreža jest mreža kanala i odvoda svih drenažnih bazena jednoga područja. Kroz drenažne kanale fluvijalni procesi djeluju na transport vode i sedimenata iz lokalne regije (O‘Callaghan i Mark, 1984). Drenažni bazen je područje zemljišta koje odvodi vodu, sedimente i druge materijale preko segmenta toka. Zbog rasprostranjenosti se umjesto naziva mrežni kanal upotrebljava segment toka (USDA, 2010). Drenažni bazeni povezuju se s drugim drenažnim bazenima na manjim nadmorskim visinama (Martz i Garbrecht, 1993; EEA Glossary, 2017; Monde Geospatial, 2017).

Geomorfolozi analiziraju geomorfometrijske parametre, opisuju padine doline i kanala, reljef, vrstu drenaže i druge parametre. Geomorfometrijska analiza drenažne mreže ima bitnu ulogu u razumijevanju geohidrološkoga ponašanja drenažnih bazena (Hajam, 2013). Ako se modeli drenažnih mreža i geomorfometrijskih parametara zajednički interpretiraju, mogu se koristiti za predviđanje poplava, modeliranje protoka vode, prepoznavanje i planiranje potencijalnih zona podzemnih voda i klimatskih studija s obzirom na to da postoji niz problema vezanih uz vodu iz učestalijih jakih kiša i masovnih poplava (Chorowicz i dr. 1992; Bognar i Faivre, 2006; Arumí i dr., 2016). Ti su modeli također korisni za vizualizaciju terena, prostorno planiranje, graditeljstvo, procjenu opasnosti (poput predviđanja i ublažavanja klizišta), obalnu zaštitu, planiranje instalacija trasa obnovljivih i neobnovljivih izvora energije i dr. (Martz i Garbrecht, 1992; Martz i Garbrecht, 1993; Soille i Gratin, 1994). 
The main aim of this research is to develop slope, aspect, and drainage network models for the territory of the Republic of Croatia. Another aim is to study each step of the development process in order to get insights into the influence of all input variables and models on the resulting models. The basis of the developed models are digital elevation models, which provide basic quantitative information of the topographic relief (Varga and Bašić, 2013).

\section{Methodology}

DEMs provide information about elevation of the Earth's topography. Although all geomorphometric parameters relate to the morphology of land surface, not all of them can be derived from a DEM without any additional information. Parameters like slope or aspect are calculated using equations, as land surface is a surface in a mathematical sense and, as such, can be derived using differential geometry (Hengl and Reuter, 2008). A value of the geomorphometric parameter for each grid node or cell is calculated using an algorithm that uses the values of the centre cell's eight neighbours with a $3 \times 3$ sized moving window.

Slope is the measure of the steepness or the degree of inclination of a surface in the tangent plane (Geokov, 2018). Slope reflects the maximal rate of change of elevation values and is defined as (Hunter and Goodchild, 1997; Olaya, 2009):

$$
S L O P E=\arctan \left(\frac{\partial z}{\partial x}, \frac{\partial z}{\partial y}\right)
$$

which indicates the angle between the $x y$-plane and plane tangential to the surface. From the above equations it follows that, for obtaining slope, first the derivatives of the plane surface in the direction of the $\mathrm{x}^{-}$and $\mathrm{y}^{-}$coordinates have to be calculated. Slope is usually expressed in percent or degrees.

Aspect is the direction of steepest slope of point or grid cell (Wilson et al., 2008). When flowing material (such as water) moves downhill under the influence of gravitational force, it will follow the direction specified by the aspect parameter (Heng1 and Reuter, 2008). It can also be used in identifying locations where the snow is likely to melt first, iden-
Glavni je cilj ovoga istraživanja izraditi model nagiba, smjera nagiba i drenažnih mreža za područje Republike Hrvatske. Uz to je cilj analizirati sve korake u postupku izrade da bi se stekao uvid o utjecaju svih ulaznih varijabla i modela na konačne modele. Osnovni podatak za izradu geomorfometrijskih modela pružaju digitalni modeli reljefa koji sadrže kvantitativne informacije topografije reljefa (Varga i Bašić, 2013).

\section{Metodologija}

Digitalni modeli reljefa pružaju informacije o visinama Zemljine topografije. Iako se svi geomorfometrijski parametri odnose na morfologiju površine Zemlje, neki od njih mogu se izračunati samo iz DMR-a bez ikakvih dodatnih podataka. Parametri poput nagiba ili smjera nagiba izračunavaju se pomoću jednadžbi gdje je površina zemljišta površina u matematičkom smislu i iz takve se može izvoditi (derivirati) diferencijalnom geometrijom (Hengl i Reuter, 2008). Vrijednost geomorfometrijskoga parametra za svaki čvor mreže ili ćeliju izračunava se s pomoću algoritma koji koristi vrijednosti osam susjeda središnje ćelije s pokretnim prozorom veličine $3 \times 3$.

Nagib je mjera strmine ili stupanj nagiba površine u tangentnoj ravnini (Geokov, 2018). Nagib opisuje maksimalnu stopu promjene vrijednosti visine i definira se kao (Hunter i Goodchild, 1997; Olaya, 2009):

$$
S L O P E=\arctan \left(\frac{\partial z}{\partial x}, \frac{\partial z}{\partial y}\right)
$$

koji se može interpretirati kao kut između ravnine xy i ravnine koja je tangencijalna na površinu. Iz gore navedene jednadžbe slijedi da za dobivanje nagiba treba izračunati prve derivacije površine $\mathrm{u} x \mathrm{i}$ $y$ smjeru. Nagib se uobičajeno izražava u postocima ili stupnjevima.

Smjer nagiba je smjer najstrmijega nagiba točke ili ćelije mreže (Wilson i dr., 2008). Kada se tekući materijal (poput vode) kreće nizbrdo pod utjecajem gravitacijske sile, slijedit će smjer određen parametrom smjera nagiba (Hengl i Reuter, 2008). Može se koristiti za identifikaciju lokacija na kojima će se prvo otopiti snijeg, za pronalaženje površina za
M. Pokupić M. Varga

T. Bašić

Models of geomorphometric parameters and drainage networks for the territory of the Republic of Croatia

Modeli geomorfometrijskih parametara $\mathrm{i}$ drenažnih mreža za prostor Republike Hrvatske 
HRVATSKI

GEOGRAFSKI

GLASNIK

80/1, 61-76 (2018.) tifying areas of flat land to find an area for a plane to land in an emergency, the best slopes for ski runs, etc. (ArcGis, 2018). Aspect is calculated according to (Hunter and Goodchild, 1997; Olaya, 2009):

$$
A S P E C T=180^{\circ}-\arctan \left(\frac{q}{p}\right)+90^{\circ} \cdot \frac{p}{|p|}
$$

Where the function is in degrees and and are first-order derivatives of the surface. The values of aspect for each computed point is the value which a compass would show for the surface at that location (ArcGIS Aspect, 2017). Usually, this is measured from north in degrees from $0^{\circ}$ to $360^{\circ}$ in the clockwise direction. The aspect model is overlapped with European river basins from The European Environment Agency.

\section{Drainage network model development}

A drainage network model is a model for water flow direction, which can be created from DEMs data using various algorithms. One of the possibilities is to use modules from GRASS (Geographic Resources Analysis Support System) software (GRASS, 2017), where the r.watershed module offers two algorithms: Single flow direction (SFD, also known as the D8) (O'Callaghan and Mark, 1984; Tarboton et el., 1991; Tarboton, 1997; Shik and Paik, 2017); and Multiple flow direction (MFD) (Freeman, 1991; Wolock and McCabe, 1995). In the SFD algorithm, the elevation of each grid cell is compared to the elevations of eight neighbouring cells, and the steepest downslope direction is assigned to each cell in the grid. The flow goes from the centre of a cell to the centre of only one surrounding cell (Tarboton et el., 1991; GRASS, 2017). With MFD algorithm, water flow is distributed to all neighbouring cells with lower elevations (Wolock and McCabe, 1995).

The r.watershed module generates a set of raster maps indicating flow accumulation, drainage direction, and location of streams and watershed basins (GRASS watershed, 2015). Stream segment and drainage basin rasters are two of the generated rasters (Fig. 1). Their names indicate what they represent, while their usable form is obtained after vectorization of the generated slijetanje zrakoplova u hitnim slučajevima, najbolje nagibe za skijaške staze itd. (ArcGis, 2018). Smjer nagiba računa se prema (Hunter i Goodchild, 1997; Olaya, 2009):

$$
A S P E C T=180^{\circ}-\arctan \left(\frac{q}{p}\right)+90^{\circ} \cdot \frac{p}{|p|}
$$

gdje je funkcija u stupnjevima, a i su prve parcijalne derivacije površine. Vrijednosti smjera nagiba za svaku izračunatu točku predstavljaju vrijednost koju bi kompas prikazao za površinu na tom mjestu ( $A r-$ cGIS Aspect, 2017). Uobičajeno se mjeri od sjevera u stupnjevima od $0^{\circ}$ do $360^{\circ}$ u smjeru kazaljke na satu. Model smjera nagiba preklopljen je s europskim riječnim bazenima iz Europske agencije za zaštitu okoliša.

\section{Kreiranje modela drenažne mreže}

Model drenažne mreže je model smjera vodenoga toka koji se može izraditi iz DMR modela primjenom nekoga od stupnih matematičkih algoritama. Jedna je od mogućnosti korištenje modula iz GRASS (eng1. Geographic Resources Analysis Support System) softvera (GRASS, 2017), gdje modul r.watershed nudi dva algoritma: algoritam jednosmjernoga protoka (SFD, također poznat kao D8) (O'Callaghan i Mark, 1984; Tarboton i dr., 1991; Tarboton, 1997; Shik i Paik, 2017) i algoritam višesmjernoga protoka (MFD) (Freeman, 1991; Wolock i McCabe, 1995). U SFD algoritmu nadmorska visina svake ćelije mreže uspoređena je s visinom osam susjednih ćelija, a najstrmiji smjer dodijeljen je svakoj ćeliji u rešetki. Tok prolazi od središta ćelije do središta samo jedne najstrmije okolne ćelije (Tarboton i dr., 1991; GRASS, 2017). Kod MFD algoritma protok vode distribuira se na sve susjedne ćelije s nižim nadmorskim visinama (Wolock i McCabe, 1995).

Modul r.watershed generira skup rastera koji upućuju na akumulaciju toka, smjer drenaže i mjesta toka i drenažnih bazena (GRASS watershed, 2015). Segmenti toka i drenažni bazeni su dva izrađena rastera (sl. 1). Njihova imena upućuju na ono što predstavljaju, dok je njihov oblik dobiven vektorizacijom generiranih rastera te je nakon njihove 


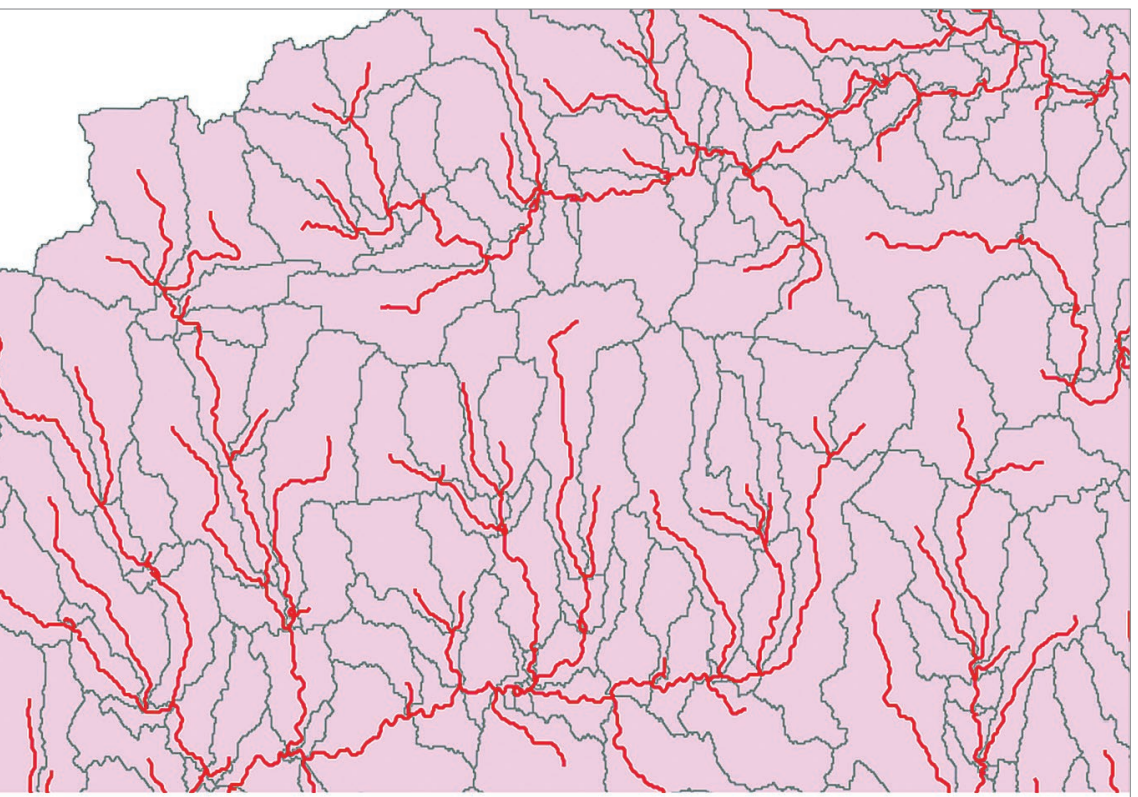

Fig. 1 Output drainage network models

SI. 1. Izlazni modeli drenažne

mreže
Legend / Legenda

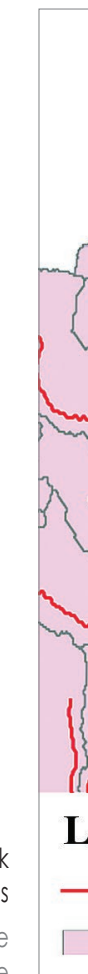

- stream segment / segment toka
M. Pokupić

M. Varga

T. Bašić

Models of geomorphometric parameters and drainage networks for the territory of the Republic of Croatia

Modeli geomorfometrijskih parametara i drenažnih mreža za prostor Republike Hrvatske rasters and after their combination drainage network model is created. The line vector layer of stream segments represent drains of all drainage basins of an area. Every stream segment has a drainage basin which drains water and dissolved materials along with it (Casper, 2007). Drainage basins are generated as polygon vector layers. Croatia abounds in a variety of relief forms and therefore drainage basins sizes and shapes, as well as lengths of stream segments, vary greatly.

For validation of the generated stream segments vector layers of developed stream segments were overlapped with the vector layer of Croatian rivers, which was obtained from EuroGlobal Map of EuroGeographic (Eurogeographics Euroglobalmap, 2017; EEA Dataset, 2017).

\section{Input data}

Nearly-global DEMs with high resolutions of 1“ have become freely accessible in the last two decades. The most significant advancement of the DEMs quality and detail was initiated by the Shuttle Radar Topography Mission (SRTM) mission in February, 2000. SRTM was flown at an approximate altitude kombinacije izrađena drenažna mreža. Linijski vektorski sloj segmenta toka predstavlja drenaže svih drenažnih bazena jednoga područja. Svaki segment toka ima drenažni bazen kroz koji odvodi vodu i otopljene materijale (Casper, 2007). Drenažni bazeni izrađeni su kao poligonski vektorski slojevi. Hrvatska obiluje varijacijama reljefa, stoga veličine i oblici drenažnih bazena kao i duljine segmenata toka znatno variraju.

$\mathrm{Za}$ provjeru ispravnosti izračunatih segmenata toka vektorski slojevi kreiranih segmenata toka preklopljeni su s vektorskim slojem hrvatskih rijeka, koji je preuzet s karte EuroGlobal (Eurogeographics Euroglobalmap, 2017; EEA Dataset, 2017).

\section{Ulazni podaci}

Globalni DMR-ovi s visokim rezolucijama od 1“ postali su posljednjih dvaju desetljeća slobodno dostupni. Najznačajniji napredak kvalitete i detaljnosti DMR-ova započeo je misijom Shuttle Radar Topography Mission (SRTM) u veljači 2000. godine. SRTM satelit letio je na približno $233 \mathrm{~km}$ nadmor- 
HRVATSKI

GEOGRAFSKI

GLASNIK

80/1, 61-76 (2018.) of $233 \mathrm{~km}$ between $60^{\circ}$ north and $56^{\circ}$ south latitudes and collected interferometric synthetic aperture radar data for approximately $80 \%$ of the Earth's land surface (Farr, 2007). Several global DEM versions were created from the collected data including SRTM1 (1“, 30 m), SRTM3 (3“, 90 m), SRTM15 (15“, 500 meters), and SRTM30 (30“, 900 meters). These versions were used as input data for creating slope, aspect and drainage network models.

\section{Study area}

The study area is within the Republic of Croatia, situated between $42.0^{\circ}-46.5^{\circ}$ north and $13.0^{\circ}-19.5^{\circ}$ east. The climatic features of this region are favourable for the development of surface watercourses. About $62 \%$ of the territory belongs to the Black Sea basin, including longest Croatian rivers-Sava, Drava, and Danube. The area of the Adriatic Sea covers $38 \%$ of the territory, its hydrographic network is smaller and its rivers have higher fall and shorter flow (Lušić and Lušić, 2011; Čanjevac, 2012; 2013). The major landcover types, calculated from the Advanced Very High-Resolution Radiometer Global Land Cover Model (AVHRR GLCM) were forests (about 30\%), scrublands and bushlands (about $30 \%$ ), croplands (about 25\%), and grasslands (about $10 \%)$. The defined study area has an elevation range of about $1700 \mathrm{~m}$, with an average slope of approximately $6^{\circ}$ (Varga and Bašić, 2015).

\section{Results and analysis}

Geomorphometric parameters and drainage network models were calculated using different input DEMs for the entire study area. All input DEMs for several selected areas, which were selected because they represent an interesting and specific topographic feature, were compared.

\section{Models of geomorphometric parameters}

Two slope models derived from SRTM3 and SRTM30 DEMs are shown and compared on Fig. 2. According to the geomorphologic classification of slopes, considering the mean slope value, for SRTM30 it is around $2^{\circ}$, which is mildly inclined ske visine između $60^{\circ}$ sjeverne i $56^{\circ}$ južne geografske širine i prikupio interferometrijske podatke sintetičkoga otvora radara za otprilike $80 \%$ površine zemlje (Farr, 2007). Neke globalne DMR inačice napravljene su iz prikupljenih podataka uključujući i modele SRTM1 (1“, 30 m), SRTM3 (3“, 90 m), SRTM15 (15“, 500 metara) i SRTM30 (30“, 900 metara). One su korištene kao ulazni podaci za kreiranje modela nagiba, smjera nagiba i drenažne mreže.

\section{Područje istraživanja}

Područje je istraživanja Republika Hrvatska, smještena u južnom dijelu srednje Europe između $42,0^{\circ}-46,5^{\circ}$ sjeverno i $13,0^{\circ}-19,5^{\circ}$ istočno. Klimatske značajke ovoga područja pogodne su za razvoj površinskih vodotoka. Oko 62 \% teritorija pripada crnomorskom slijevu, uključujući i najduže rijeke Savu, Dravu i Dunav. Jadranski slijev obuhvaća $38 \%$ područja, njegova hidrografska mreža je manja, a rijeke imaju veći pad i kraći tok (Lušić i Lušić, 2011; Čanjevac, 2012; 2013). Glavne vrste pokrova površine, dobivene iz Globalnoga modela kopnene pokrivenosti (AVHRR GLCM), čine šume (oko $30 \%$ ), šikare i grmlje (oko $30 \%$ ), usjevi (oko $25 \%$ ) i travnjaci (oko $10 \%$ ). Definirano područje istraživanja ima visinski raspon od oko 1700 $\mathrm{m}, \mathrm{s}$ prosječnim nagibom od približno $6^{\circ}$ (Varga i Bašić, 2015).

\section{Rezultati i analiza}

Modeli geomorfometrijskih parametara i drenažne mreže izračunati su s pomoću različitih ulaznih DMR-ova za cijelo područje istraživanja. Usporedba svih ulaznih DMR-ova obavljena je na nekoliko odabranih područja koja predstavljaju zanimljive i specifične topografske značajke.

\section{Modeli geomorfometrijskih parametara}

$\mathrm{Na}$ sl. 2 prikazana su i uspoređena dva modela nagiba izračunata iz SRTM3 i SRTM30 DMRova. Prema geomorfološkoj klasifikaciji padina, ako uzmemo u obzir srednju vrijednost nagiba, za SRTM30 iznosi oko $2^{\circ}$, što je blago nagnut te- 




Fig. 2 SRTM3 and SRTM30 slope models of Croatia

SI. 2. SRTM3 i SRTM30 modeli nagiba za Hrvatsku

terrain, while for SRTM3 it is $5^{\circ}$, which is inclined terrain. Geomorphologic classification of slopes is based on dominant morphological processes, which are active in relation to steepness, as well as related terrain shapes (Bashenina, 1966). The biggest differences between slope models were observed in the central and eastern parts Croatia. Some slopes, which have values larger than $5^{\circ}$, are not represented on the SRTM30 slope model as small differences are evidently missing when lower resolution DEMs are used. If we analyse the whole study area, SRTM3 gives more detailed and credible representation of slopes of different categories that change even in very small areas. According to SRTM30 model, the steepest slope is $32^{\circ}$, while on SRTM3 model, the steepest slope is $55^{\circ}$. According to the SRTM3 slope model, the lowest slopes are in eastern Slavonia, western Istria, northern Dalmatia, and in valleys along the Drava and Sava rivers. Inclined terrain with slopes from $5-12^{\circ}$ dominate in the areas of Lika and Gorski Kotar. In central Croatia, this slope occurs on Žumberačko Gorje, Medvednica, Petrova Gora, and in central Slavonia. Slope models from SRTM3 DEMs show larger relief structures and features, like Ličko Polje, whose slopes are about $2^{\circ}$, next to Velebit Mountain where slopes reach values up to $32^{\circ}$.

Paklenica national park is a good example of extreme values of slopes, chosen for comparison of slope models of all input DEMs (Fig. 3). On ren, dok za SRTM3 iznosi $5^{\circ}$, što je nagnut teren. Geomorfološka klasifikacija padina temelji se na dominantnim morfološkim procesima koji se aktiviraju u odnosu na strmost, kao i srodne oblike terena (Bashenina, 1966). Najveće razlike između modela nagiba uočene su u središnjoj i istočnoj $\mathrm{Hr}$ vatskoj. Neki nagibi koji imaju vrijednosti veće od $5^{\circ}$ nisu prikazani na modelu nagiba iz SRTM30 jer se male razlike očito ne pojavljuju kada se koriste DMR-ovi niže rezolucije. Ako analiziramo cijelo područje istraživanja, SRTM3 ima detaljniji i vjerodostojniji prikaz nagiba različitih kategorija koje se mijenjaju, čak i u vrlo malim područjima. Prema SRTM30 modelu najstrmiji nagib je $32^{\circ}$, dok je na SRTM3 modelu najstrmiji nagib $55^{\circ}$. Prema modelu nagiba iz SRTM3 najniži su nagibi u istočnoj Slavoniji, zapadnoj Istri, sjevernoj Dalmaciji i dolinama rijeke Drave i Save. Na području Like i Gorskoga kotara dominira nagnuti teren s nagibima od $5^{\circ}$ do $12^{\circ}$. U Središnjoj Hrvatskoj taj se nagib javlja na Žumberačkom gorju, Medvednici, Petrovoj gori i u središnjoj Slavoniji. Model nagiba iz SRTM3 DMR-a otkriva veće reljefne strukture i značajke, kao što je npr. Ličko polje, čiji su nagibi oko $2^{\circ}$, uz planinu Velebit gdje nagibi dostižu vrijednosti do $32^{\circ}$.

Nacionalni park Paklenica dobar je primjer ekstremnih vrijednosti nagiba te je odabran za usporedbu modela nagiba svih ulaznih DMR-ova
Models of geomorphometric parameters and drainage networks for the territory of the Republic of Croatia

Modeli geomorfometrijskih parametara $\mathrm{i}$ drenažnih mreža za prostor Republike Hrvatske 
HRVATSKI

GEOGRAFSKI

GLASNIK

80/1, 61-76 (2018.)

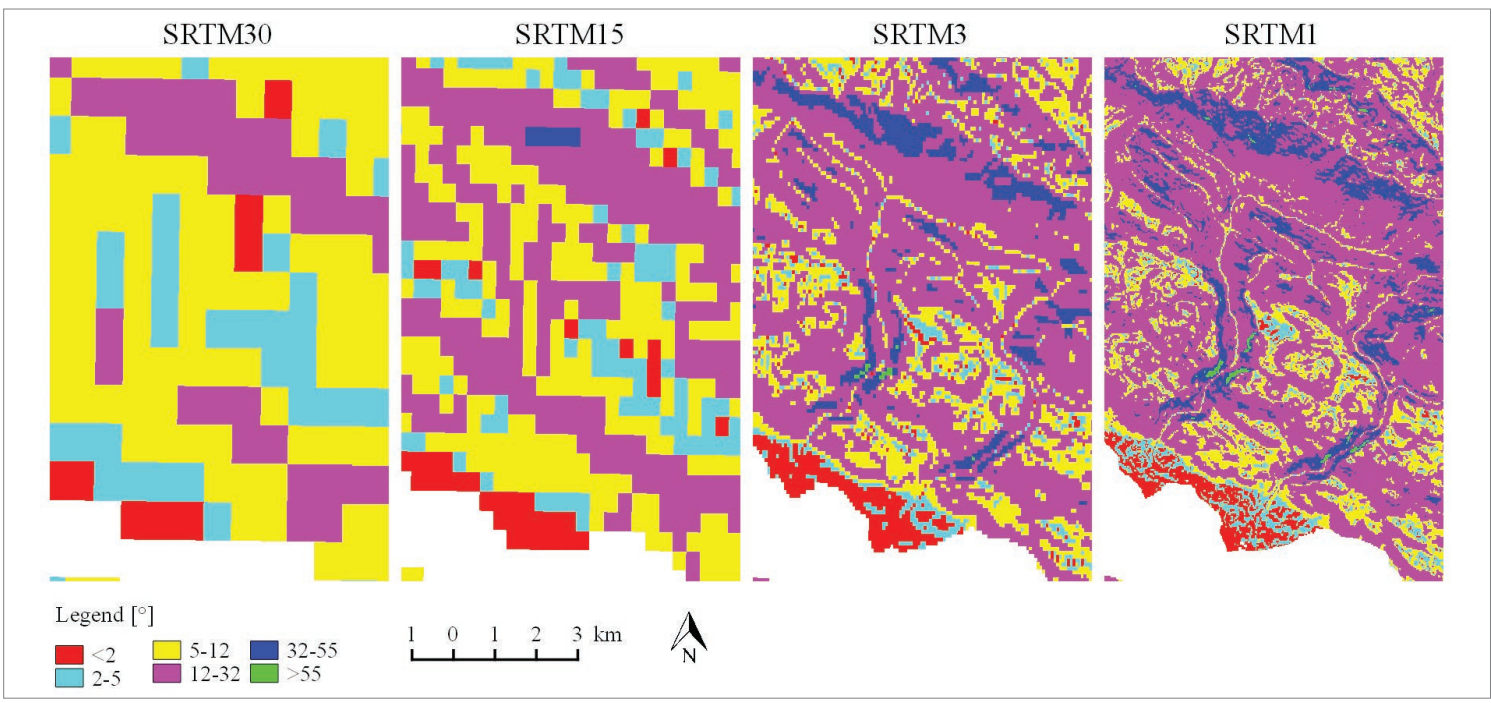

Fig. 3 SRTM30, SRTM15, SRTM3 and SRTM1 slope models of Paklenica national park SI. 3. SRTM30, SRTM15, SRTM3 i SRTM1 modeli nagiba za Nacionalni park Paklenica

high-resolution DEMs, especially on SRTM1, it is easy to recognise the Small and Great Paklenica canyons. If we observe change around the canyons, we see how the details of the slope representation drastically decrease with smaller resolution. In SRTM1, some inclines are greater than $55^{\circ}$, while in SRTM30, there is no inclination greater than $30^{\circ}$. Slope models from SRTM15 and SRTM30 DEMs did not even recognised canyons whose extreme values are of great significance, because in that area dispersal and collapsing of material is dominant. It can be concluded that slope models from SRTM15 and especially SRTM30 DEMs are very rough and do not represent the area realistically.

As stated earlier in the paper, an aspect model indicates the flow direction of flowing material measured clockwise from the north in degrees from 0 to 360. Although the aspect map from the SRTM30 DEM may be simpler for observation and analysis, the aspect model from the SRTM3 DEM is more accurate and realistic (Fig. 4). SRTM30 has larger areas in one colour, i.e. the same direction, while SRTM3 has more details in the same observed areas, i.e. differently aligned slopes. Most slopes in both models, over the coastal line, are oriented towards the south. In the northern part of study area (Bilogora - a low hill which stretches along Drava River) is oriented towards the north. Along with the Sava River, a line of south-facing slopes stands out. (sl. 3). Na DMR-ovima visoke rezolucije, osobito na SRTM1, lako je za prepoznati kanjone Male i Velike Paklenice. Ako promatramo promjenu oko kanjona, vidimo kako se detalji prikaza nagiba drastično smanjuju s manjom rezolucijom. $\mathrm{Na}$ SRTM1 neki nagibi veći su od $55^{\circ}$, dok na SRTM30 ne postoji nagib veći od $30^{\circ}$. Modeli nagiba iz SRTM15 i SRTM30 DMR-ova nisu ni prepoznali kanjone čije su ekstremne vrijednosti od velike važnosti jer u tom području prevladava rasipanje i urušavanje materijala. Može se zaključiti da su modeli nagiba iz SRTM15 te posebno iz SRTM30 DMR-a vrlo grubi i ne predstavljaju područje vjerodostojno.

Kao što je već rečeno, model smjera nagiba upućuje na smjer protoka tekućega materijala te je mjeren u smjeru kazaljke na satu od sjevera u stupnjevima od 0 do 360. Iako je karta smjera nagiba iz SRTM30 DMR-a jednostavnija za promatranje i analizu, model smjera nagiba iz SRTM3 DMR-a točniji je i vjerodostojniji (sl. 4). SRTM30 ima veća područja u jednoj boji, tj. u istom smjeru, dok SRTM3 ima više detalja u istim promatranim područjima, tj. različito usmjerene nagibe. Većina nagiba uz obalnu liniju, u oba modela, orijentirana je prema jugu. Na sjeveru područja, nagibi niskoga brežuljka (Bilogora), koji se proteže duž rijeke Drave, usmjereni su prema sjeveru. Uz rijeku Savu ističe se linija nagiba okrenutih prema jugu. 


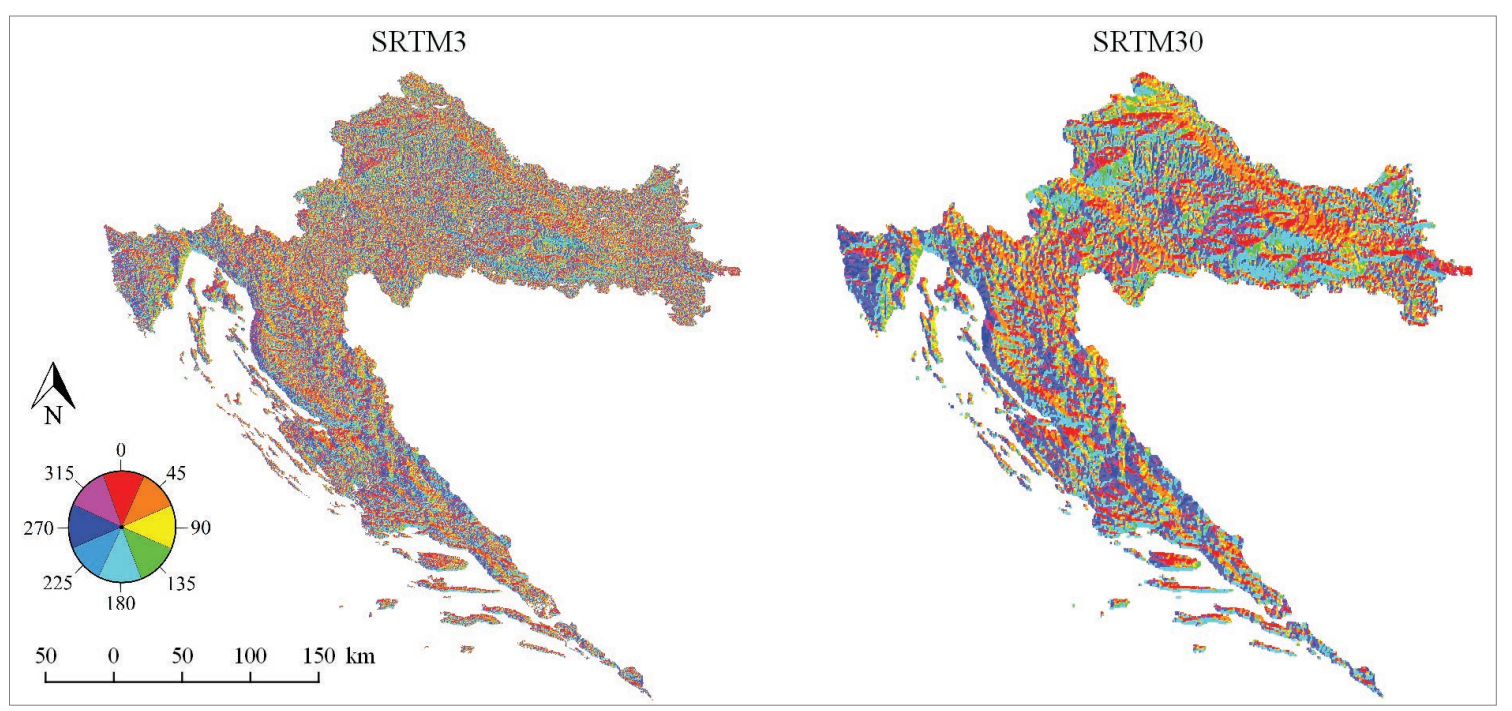

M. Pokupić

M. Varga

T. Bašić

Models of

geomorphometric

parameters and

drainage networks

for the territory

of the Republic of

Croatia

Modeli

geomorfometrijskih

parametara i

drenažnih mreža za

prostor Republike

Hrvatske

Fig. 4 SRTM3 and SRTM30 aspect models of Croatia

SI. 4. SRTM3 i SRTM30 modeli smjera nagiba za HrvatskU

Although values of aspect parameter can't be observed as values of slope parameter, the Paklenica national park was again chosen for comparison of aspect models of all input DEMs because of its specific relief forms (Fig. 5). The quality of the results of the aspect models for selected DEMs is comparable to the results of the slope models. In SRTM3, and especially in SRTM1, the relief is represented very realistically: it is easy to imagine the tops of mountains and their slopes. We can even recog-
Iako se vrijednosti smjera nagiba ne mogu promatrati kao vrijednosti nagiba, Nacionalni park $\mathrm{Pa}$ klenica ponovno je odabran za usporedbu modela smjera nagiba svih ulaznih DMR-ova zbog specifičnih oblika reljefa (sl. 5). Kvaliteta rezultata modela smjera nagiba za odabrane DMR-ove usporediva je s rezultatima modela nagiba. Na SRTM3, a posebno na SRTM1, reljef je vrlo realno prikazan: lako je zamisliti vrhove planina i njihove nagibe. $\mathrm{Na}$ modelu smjera nagiba možemo čak prepoznati

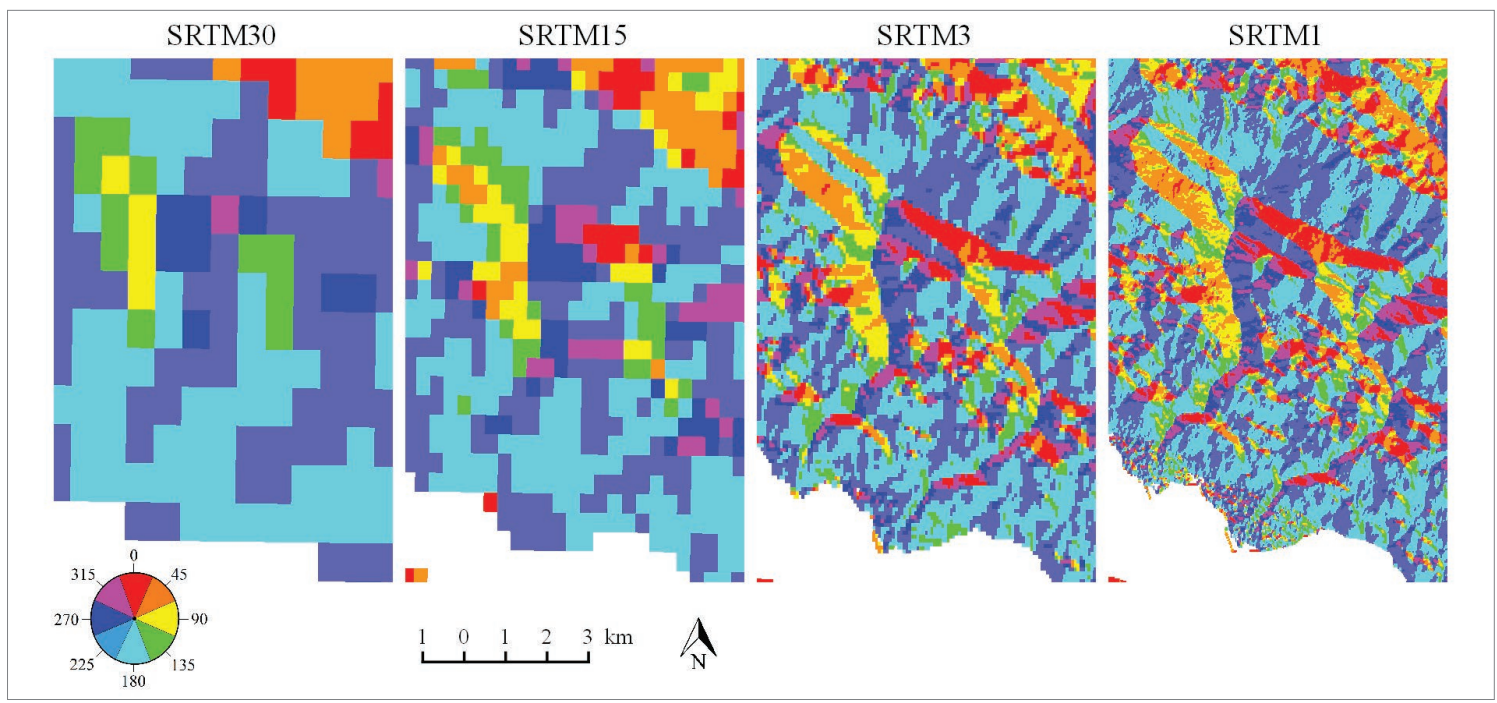

Fig. 5 SRTM30, SRTM15, SRTM3 and SRTM1 aspect models of Paklenica national park

SI. 5. SRTM30, SRTM15, SRTM3 i SRTM1 modeli smjera nagiba za Nacionalni park Paklenica 
HRVATSKI

GEOGRAFSKI

GLASNIK

80/1, 61-76 (2018.) nise the canyons in the aspect models, which are not recognizable on the slope models. Unlike with high-resolution DEMs, in SRTM15 and SRTM30 models, the canyons do not exist, and the difference between SRTM1 and SRTM30 model is drastic.

This level of detail and representation of both geomorphometric parameters of canyons may be crucial for some applications, such as navigation.

Validation of the aspect model was done by comparison and overlap with an independent dataset polygon vector layer of European river basins, obtained from the European Environment Agency (Fig. 6 right, EEA Dataset, 2017). The SRTM3 aspect model was used because of its representative quality compared to other created models. There are two such large basins across the study area: $62 \%$ of the territory belongs to the Black Sea Basin and the 38\% to the Adriatic Sea Basin. It is a confirmation of the existing border between the polygons of the Black Sea Basin and the Adriatic Sea Basin. The border between these two basins goes over the top of the Dinarides kanjone koji nisu prepoznatljivi na modelima nagiba. Za razliku od DMR-ova visoke rezolucije, na modelima SRTM15 i SRTM30 kanjoni ne postoje, dok je razlika između modela SRTM1 i SRTM30 drastična.

Takva razina detaljnosti prikaza kanjona s obama geomorfometrijskim parametrima može biti presudna za neke primjene, kao što je primjerice navigacija.

Kontrola izrađenih modela smjera nagiba obavljena je usporedbom i preklapanjem s neovisnim poligonskim vektorskim slojem europskih riječnih bazena preuzetog sa stranice Europske agencije za zaštitu okoliša (sl. 6 desno, EEA Dataset, 2017). Model smjera nagiba iz SRTM1 upotrijebljen je zbog reprezentativne kvalitete u usporedbi s ostalim modelima. Postoje dva takva velika bazena na području istraživanja: $62 \%$ teritorija pripada crnomorskom slijevu i $38 \%$ jadranskom slijevu. Model smjera nagiba potvrda je postojeće granice između poligona crnomorskoga i jadranskoga slijeva. Granica između tih dvaju bazena ide pre-
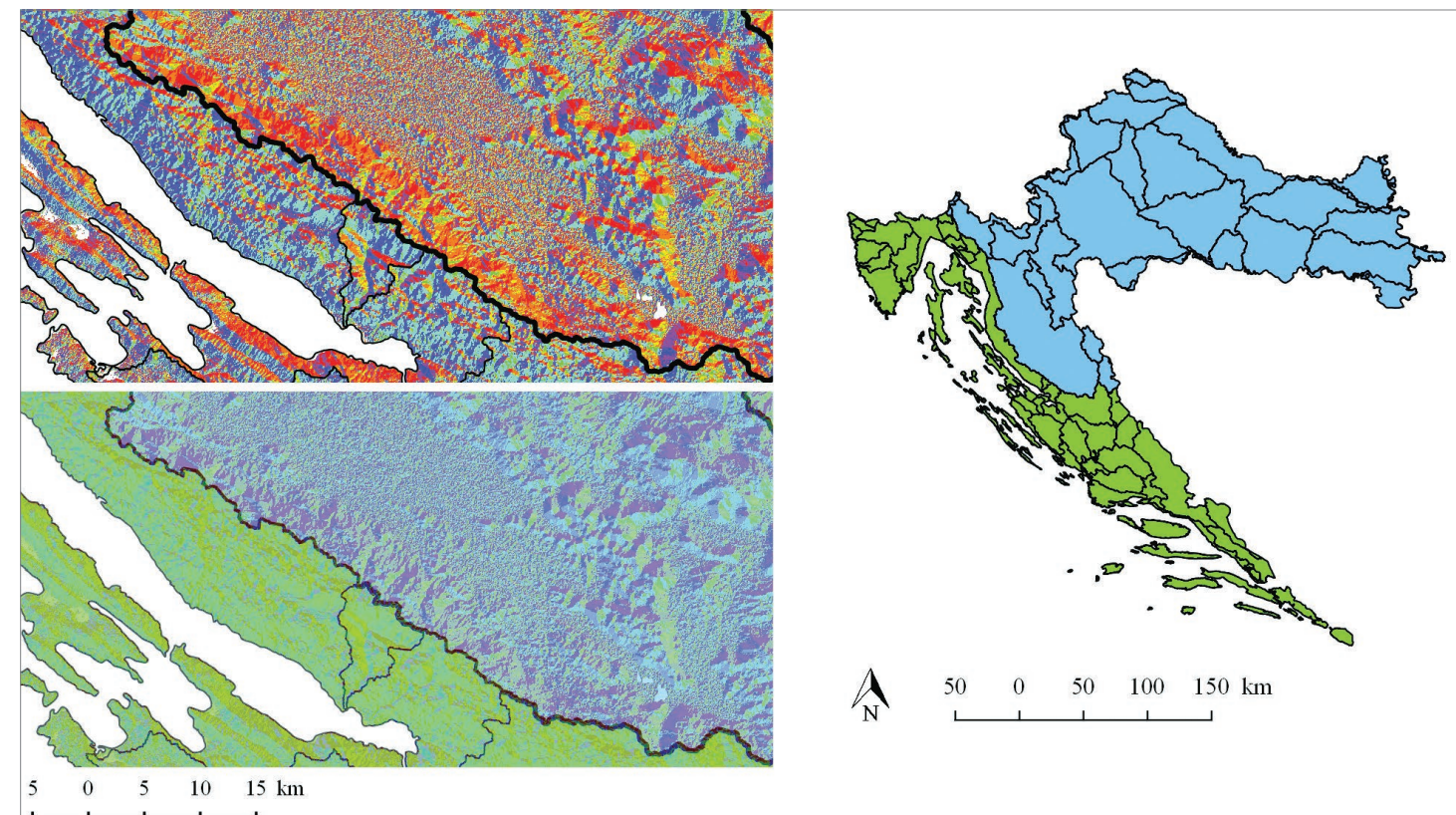

Legend / Legenda
$\square$ Black Sea Basin / Crnomorski slijev
$\square$ Adriatic Sea Basin / Jadranski slijev
- boundary / granica

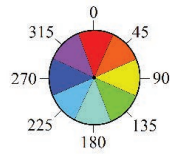

Fig. 6 Border between Black Sea Basin and Adriatic Sea Basin by SRTM3 aspect model SI. 6. Granica između crnomorskoga i jadranskoga slijeva prema SRTM1 modelu smjera nagiba 
(Lušić and Lušić, 2011). Some of the most important mountains of the Dinarides, which form part of the border between the basins, are: Risnjak; Velika Kapela; Velebit; and Dinara. Our aspect model showed that the boundary between these two basins really follows tops of the mountains. Fig. 6 left is an example of Velebit Mountain where it is clear to see that the line of mountain tops is where the red and cyan colours meet, i.e. slopes that are counter-oriented.

\section{Drainage network models}

In order to calculate drainage network models, the main input values are DEMs of the specified resolution and type of algorithm. Output models, stream segment and drainage basins, were calculated with SFD and MFD algorithms for the whole study area, from the SRTM3, SRTM15, and SRTM30 DEMs.

\section{Differences depending on the implemented algorithm}

Drainage network models obtained by using SFD and MFD algorithms gave very similar results. As the resolution of DEMs decreases, the similarities between models are smaller. This was also true for matching of the results of algorithms with the vector layer of rivers. The higher the resolution was, the ko vrha Dinarida (Lušić i Lušić, 2011). Risnjak, Velika Kapela, Velebit i Dinara neke su od najvažnijih planina Dinarida, koje su granica bazena. Naš model smjera nagiba pokazao je da granica između tih dvaju bazena doista slijedi vrh planine. Na sl. 6 lijevo prikazan je Velebit gdje se jasno vidi linija planinskih vrhova između crvene i tirkizne boje, tj. područje gdje graniče nagibi koji su obrnuto orijentirani.

\section{Modeli drenažne mreže}

Za računanje modela drenažnih mreža ulazni modeli su digitalni modeli reljefa određene rezolucije uz odabir algoritma računanja. Izlazni modeli, segment toka i drenažni bazeni izračunati su uporabom SFD i MFD algoritama za cijelo područje istraživanja iz SRTM3, SRTM15 i SRTM30 DMR-ova.

\section{Razlike između modela drenažne mreže s obzirom na korišteni algoritam}

Modeli drenažnih mreža dobiveni uporabom SFD i MFD algoritama dali su vrlo slične rezultate. Kako se rezolucija DMR-a smanjuje, sličnosti između modela su manje. To vrijedi i za podudaranje rezultata algoritama s vektorskim slojem rijeka. Što je rezolucija veća, rezultati su točniji.

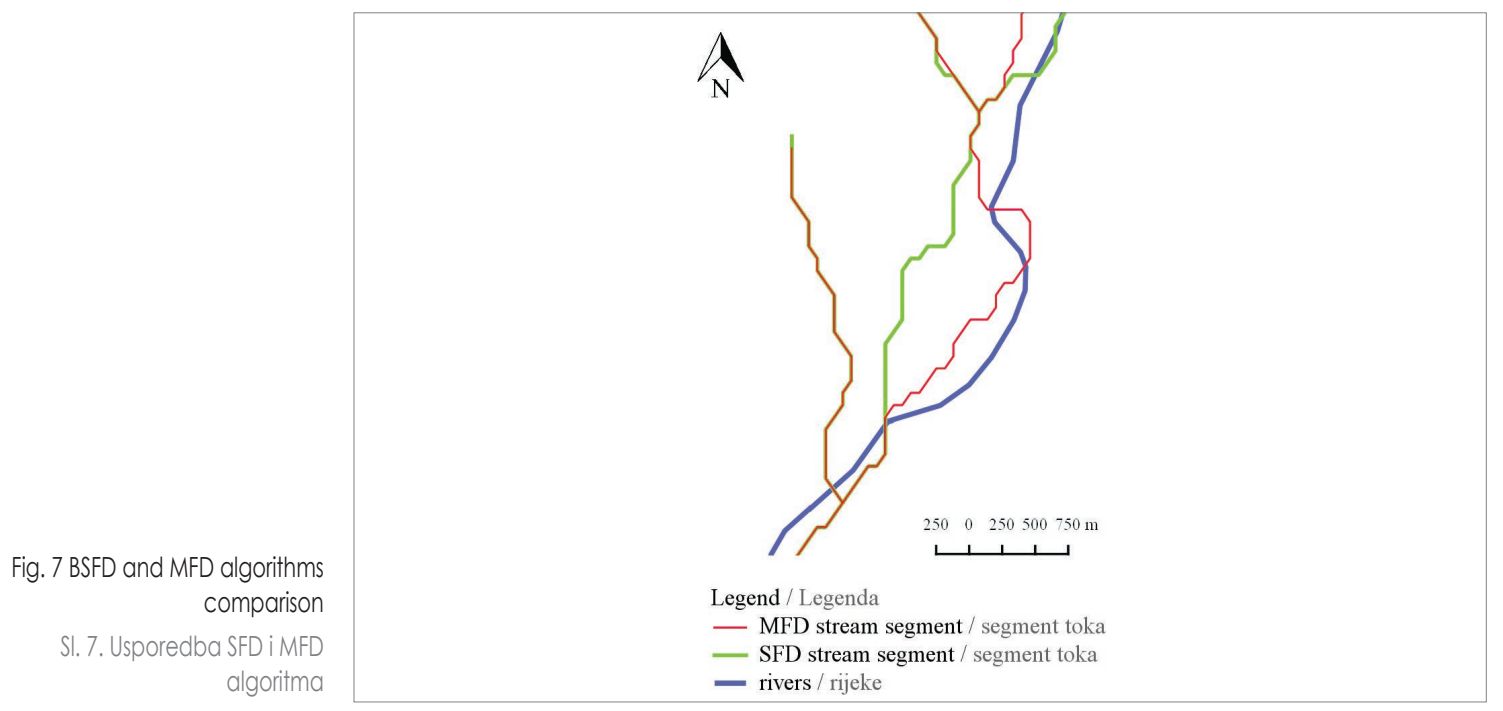


HRVATSKI

GEOGRAFSKI

GLASNIK

80/1, 61-76 (2018.) more accurate the results. Comparison of both algorithms with vector layer of Croatian rivers showed that in few places the MFD algorithm produced more reliable and denser drainage pattern compared to the SFD algorithm (Fig. 7). Therefore the MFD algorithm was used for further comparison of drainage network models depending on the DEM used.

\section{Differences between drainage network models depending on the DEM used}

Differences in drainage network models were significant when DEMs with different resolution were used (Fig. 9). Because of its high resolution, SRTM1 provided the most accurate results but the calculating time for the whole territory increased exponentially and became unrealistically large, so calculations were done only for the test area (about $2000 \mathrm{~km}^{2}$ ). When the whole study area was compared between the stream segment models, the expected was confirmed (Fig. 8). The SRTM3 model is considerably denser, but the difference in accuracy is visible only in the smaller, local area where it is more transparent for the analysis.

Drainage network models depending of different input DEMs were analysed for the area of Medvednica hill, surrounded by the Krapina and Sava rivers (Fig. 9). SRTM30 and SRTM15 provided rough results because of their low resolution. Their stream seg-
Usporedba obaju algoritma s vektorskim slojem hrvatskih rijeka pokazuje da MFD algoritam u nekoliko mjesta daje pouzdaniji i gušći uzorak drenaže u usporedbi sa SFD algoritmom (sl. 7). Stoga je algoritam MFD korišten za daljnju usporedbu modela drenažne mreže ovisno o korištenom DMR-u.

\section{Razlike između modela drenažne mreže s obzirom na korišteni DMR}

Razlike u drenažnim mrežama značajne su kad se koriste DMR-ovi različitih rezolucija (sl. 9) Zbog svoje visoke rezolucije SRTM1 pružio je najtočnije rezultate, ali vrijeme izračunavanja za cijelo područje povećava se eksponencijalno i postaje nerealno dugo pa su izračuni obavljeni samo za testno područje (oko $2000 \mathrm{~km}^{2}$ ). Kad se za cijeli prostor ispitivanja usporede modeli segmenta toka, potvrđeno je ono što se očekivalo (sl. 8). Model SRTM3 znatno je gušći, ali razlika u točnosti vidljiva je samo u manjoj, lokalnoj površini jer je ona transparentnija za analizu.

Modeli drenažnih mreža ovisno o različitim ulaznim DMR-ovima analizirani su na području gore Medvednice okružene rijekama Krapinom i Savom (sl. 9). SRTM30 i SRTM15 pružili su grube rezultate zbog svoje niske rezolucije. Njihovi segmenti



Fig. 8 SRTM3 and SRTM30 stream segments of Croatia SI. 8. Segmenti toka za Hrvatsku iz SRTM3 i SRTM30 


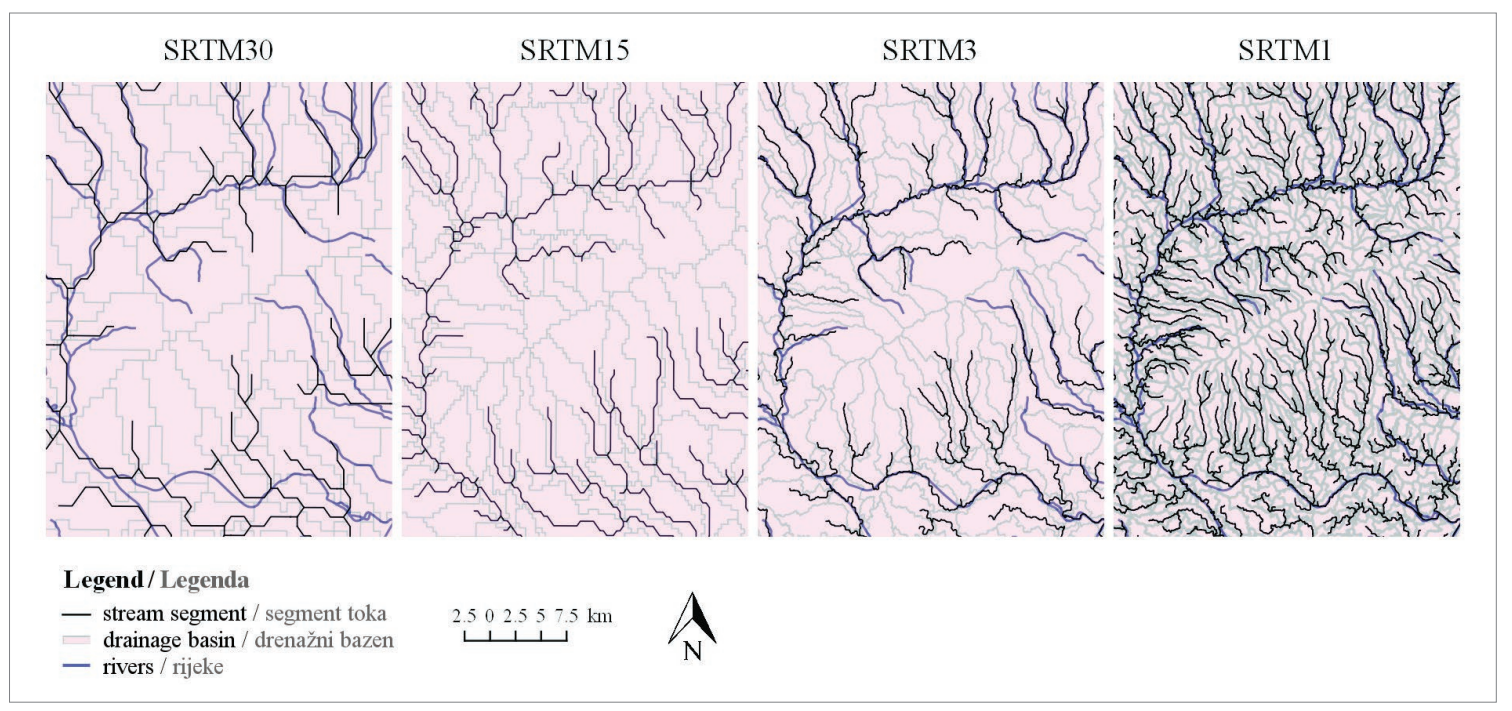

Models of geomorphometric parameters and drainage networks for the territory of the Republic of Croatia

Modeli geomorfometrijskih parametara $\mathrm{i}$ drenažnih mreža za prostor Republike Hrvatske

Fig. 9 SRTM30, SRTM15, SRTM3 and SRTM1 drainage network models comparison SI. 9. Usporedba SRTM30, SRTM15, SRTM3 I SRTMI modela drenažne mreže

ments are mostly river channels and they appear quite unnatural because they follow the river very roughly (stream segments are mostly straight lines). Recall that stream segments are not just river channels, but all the channels through which rainfalls flow. Better resolution of DEMs requires longer calculating time and because of that the module generates more drainage basins, smaller basin area, and shorter stream segments than with lower resolution, which we can see from Tab 1. Because of this, it is expected that SRTM3 and SRTM1 would provide better and more accurate results. It is clearly visible from visual comparison how SRTM1 stands out for its density and very natural appearance, and in most cases, rivers and stream segments are quite compatible (about 90\%). toka uglavnom su riječni kanali i izgledaju sasvim neprirodno dok prate rijeku vrlo grubo (segmenti toka uglavnom su ravne linije). Sjetimo se da segmenti toka nisu samo riječni kanali, već svi kanali kroz koje bi padaline prolazile. Bolja rezolucija DMR-a zahtijeva duže vrijeme izračunavanja i zbog toga modul stvara više drenažnih bazena, bazene manje površine i kraće segmente toka nego s nižom rezolucijom, što možemo vidjeti iz tablice 1 . Zbog toga se i očekivalo da će SRTM3 i SRTM1 dati realističnije rezultate. Jasno je vidljivo iz vizualne usporedbe kako se SRTM1 ističe po svojoj gustoći i vrlo prirodnom izgledu te su u većini slučajeva rijeke i segmenti toka prilično kompatibilni (oko $90 \%$ ).

Tab. 1 Threshold values of drainage network models created from different input DEMs and algorithms Tab. 1. Vrijednosti modela drenažne mreže izračunati iz različitih algoritama i ulaznih DMR-ova

\begin{tabular}{|c|c|c|c|c|c|c|c|c|}
\hline \multicolumn{2}{|c|}{} & \multicolumn{4}{c|}{$\begin{array}{c}\text { Watershed basin area } \\
\text { / Površina drenažnoga bazena }\end{array}$} & \multicolumn{3}{c|}{$\begin{array}{c}\text { Stream segment length } \\
\text { / Duljina segmenta toka }\end{array}$} \\
\hline $\begin{array}{c}\text { DEM } \\
\text { / DMR }\end{array}$ & $\begin{array}{c}\text { Algorithm } \\
/ \text { Algoritam }\end{array}$ & $\begin{array}{c}\text { Number } \\
/ \text { Broj }\end{array}$ & $\begin{array}{c}\text { Max }\left(\mathrm{km}^{2}\right) \\
/ \text { Maksimum }\end{array}$ & $\begin{array}{c}\text { Min }\left(\mathrm{km}^{2}\right) \\
/ \text { Minimum }\end{array}$ & $\begin{array}{c}\text { Avg }\left(\mathrm{km}^{2}\right) \\
/ \text { Srednje }\end{array}$ & $\begin{array}{c}\text { Max (km) } \\
/ \text { Maksimum }\end{array}$ & $\begin{array}{c}\text { Min }(\mathrm{m}) \\
/ \text { Minimum }\end{array}$ & $\begin{array}{c}\text { Avg }(\mathrm{km}) \\
/ \text { Srednje }\end{array}$ \\
\hline \multirow{2}{*}{ SRTM3 } & SFD & 3680 & 144.902 & 0.009 & 19.072 & 33.70 & 93 & 3.78 \\
\cline { 2 - 9 } & MFD & 4863 & 155.494 & 0.009 & 14.406 & 31.77 & 93 & 2.85 \\
\hline \multirow{2}{*}{ SRTM15 } & SFD & 2386 & 178.781 & 0.215 & 29.181 & 47.94 & 464 & 4.31 \\
\cline { 2 - 10 } & MFD & 2355 & 211.482 & 0.215 & 29.407 & 38.17 & 464 & 4.21 \\
\hline \multirow{2}{*}{ SRTM30 } & SFD & 1936 & 265.052 & 0.861 & 35.737 & 39.25 & 928 & 4.67 \\
\cline { 2 - 9 } & MFD & 1566 & 216.000 & 0.861 & 43.679 & 39.09 & 928 & 5.06 \\
\hline
\end{tabular}


HRVATSKI

GEOGRAFSKI

GLASNIK

80/1, 61-76 (2018.)

\section{Overlap}

The geomorphometric parameters and drainage network models derived from the SRTM1 DEM have been overlapped. Fig. 10 shows an area of Medvednica hill and the Krapina and Sava rivers where stream segments are overlapped with aspect and slope models. The first overlap with the aspect model allows us to see a 3D illusion of the top of Medvednica hill and the way stream segments start from the top of Medvednica, passing between the slopes all the way to the flat valley of the Sava River to drain off into a river, is clearly visible. The overlap with slope model shows how the canyon of the Krapina river, which is on level ground $\left(<2^{\circ}\right)$, stands out because of its location between two areas of inclined terrain $\left(2^{\circ}-12^{\circ}\right)$. Analysed together this provides a better understanding of the terrain, which is the main objective in geomorphometric analysis.

Understanding the terrain is particularly important at the regional level, e.g. for the needs of rural development. According to Pejnović et al. (2017), for the purpose of rural development, among other things, member states of the European Union promote sustainable forest management, risk management in agriculture, regeneration, conservation, improvement of the ecosystem, and sustainable use of resources. Created models, especially drainage network models, can serve to achieve these goals.

\section{Preklop}

Modeli geomorfometrijskih parametara i drenažne mreže izračunati iz SRTM1 DMR-a su preklopljeni. Na slici 10 prikazano je područje gore Medvednice te rijeke Krapine i Save, gdje se segmenti toka preklapaju s modelima nagiba i smjera nagiba i nagiba. Prvi preklop s modelom smjera nagiba omogućuje nam da vidimo 3D prikaz vrha gore Medvednice i jasno je vidljivo kako segmenti toka počinju na vrhu Medvednice, prolaze između nagiba sve do ravnih dolina rijeka Save i Krapine da se isprazne u njih. Preklop s modelom nagiba pokazuje kako se kanjon rijeke Krapine koji se nalazi na ravnom tlu $\left(<2^{\circ}\right)$ ističe zbog položaja između nagnutoga terena $\left(2^{\circ}-12^{\circ}\right)$. Analizirani zajedno pružaju bolje razumijevanje terena koji je glavni objekt u geomorfometrijskoj analizi.

Razumijevanje terena posebice je bitno na regionalnoj razini, primjerice za potrebe ruralnoga razvoja. Prema Pejnović i dr. (2017) države članice Europske unije za potrebe ruralnoga razvoja potiču između ostaloga održivo upravljanje šumama, upravljanje rizikom u poljoprivredi, obnavljanje, očuvanje i poboljšanje ekosustava te održivo korištenje resursa. Kreirani modeli, posebice modeli drenažnih mreža, mogu poslužiti u ostvarenju tih ciljeva.

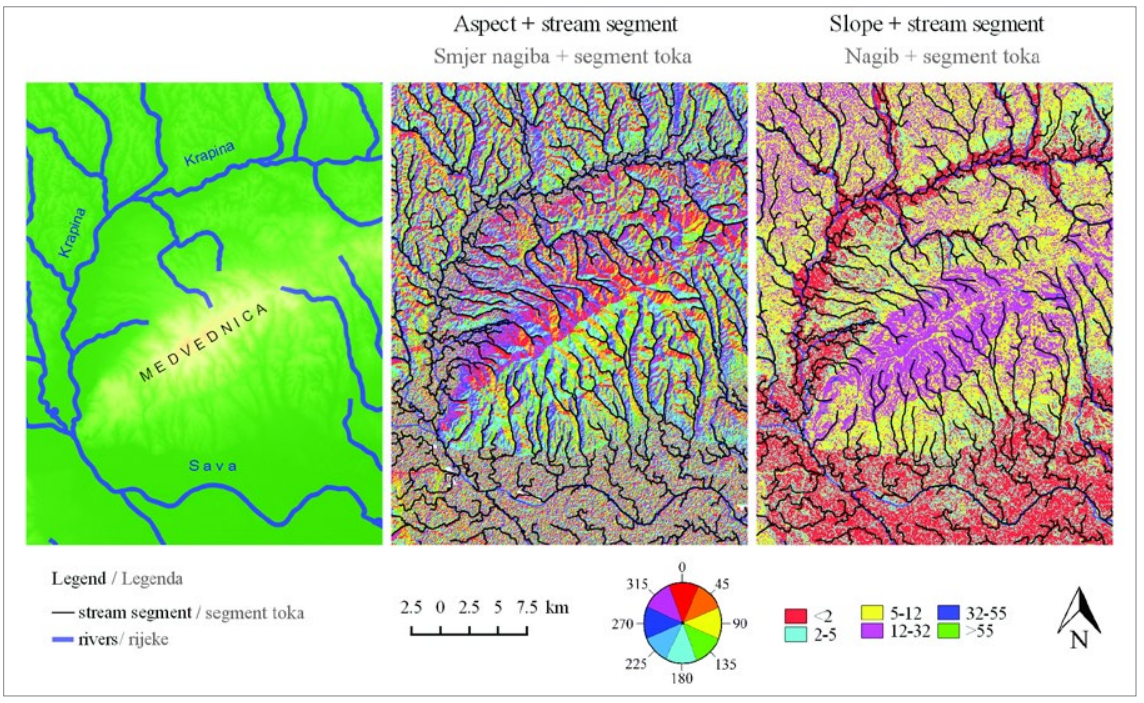

Fig. 10 Aspect and slope models joined with stream segments

SI. 10. Modeli smiera nagiba i nagiba zajedno s modelom segmenata toko 


\section{Conclusion}

Slope, aspect, and drainage network models for the territory of the Republic of Croatia have, in the scope of this research, been created for the first time using different input DEMs. Optimal models of geomorphometric parameters slope and aspect have been obtained using the most detailed DEMs. For the computing the drainage network model, it was expected that DEMs with higher resolution would provide the best results, but considering long computing time, the optimal model was obtained with SRTM3. Although there were small differences, drainage network models derived by the MFD algorithm were more realistic than those derived using the SFD algorithm. All models were compared with independent data. The results of comparison confirmed their reliability. Overlay of slope and aspect models with drainage network model showed their common utility and possible applicability in large numbers of cases.

\section{Supplementary material}

High-resolution grids and maps of slope, aspect and drainage networks for the territory of Republic of Croatia are attached to this paper and may be downloaded here: (https://geofhr-my.sharepoint.com/:f:/g/personal/ mvarga_geof_hr/E19bdFIP7VZOshAerzYibWoBYktoKkYCIb2go619nVtrFg?e=x7aKeY). Grids are provided in georeferenced TIFF format, whereas corresponding maps are given in PNG format. All models and maps may be used in scientific and civilian community without any restriction or limitation.

\section{Zaključak}

Modeli nagiba, smjera nagiba i drenažnih mreža prvi su put kreirani za područje Republike Hrvatske uporabom različitih ulaznih DMR-ova. Optimalni modeli geomorfometrijskih parametara nagiba i smjera nagiba dobiveni su s pomoću najdetaljnijega DMR-a. Za izračun modela drenažne mreže očekivalo se da će DMR s većom rezolucijom pružiti najbolje rezultate, ali s obzirom na prihvatljivo vrijeme računanja dobiva se optimalni model s SRTM3. Iako postoje male razlike, modeli odvodne mreže izvedeni s pomoću MFD algoritma realniji su od onih izvedenih s pomoću SFD algoritma. Svi modeli uspoređeni su s nezavisnim podacima. Rezultati usporedbe potvrdili su njihovu pouzdanost. Preklop modela nagiba i smjera nagiba s modelom drenažne mreže pokazuje njihovu zajedničku korisnost i moguću uporabu za velik broj namjena, posebice za ruralni razvoj na regionalnoj razini.

\section{Dodatni materijali}

Modeli i slike nagiba, smjera nagiba i drenažnih mreža u visokoj rezoluciji za prostor Republike Hrvatske mogu se preuzeti s poveznice (https://geofhr-my. sharepoint.com/:f:/g/personal/mvarga_geof_hr/E19bdFIP7VZOshAerzYibWoBYktoKkYCIb2go619nVtrFg?e=x7aKeY). Modeli su izrađeni u georeferenciranom TIFF formatu, dok su slike izrađene u PNG formatu. Svi objavljeni modeli mogu se upotrebljavati u znanstvene i civilne potrebe bez ikakve iznimke i ograničenja.
ArcGIS Aspect, http://desktop.arcgis.com/ en/arcmap/10.3/tools/spatial-analyst-toolbox/how-aspect-works.htm (21. 02. 2018.).

Arumí, J. L., Maureira, H., Souvignet, M., Pérez, C., Rivera, D., Oyarzún, R., 2016: Where does the water go? Understanding geohydrological behaviour of Andean catchments in south-central Chile, $\mathrm{Hy}$ drological Sciences Journal 61 (5), 844-855, DOI: $10.1080 / 02626667.2014 .934250$

Bashenina, N. V., Gellert, J., Joly, F., Klimaszewski, M., Scholz, E., 1966: The unified key to the detailed Geomorphological Map, IGU Commission on Applied Geomorphology, Krakow, Poland.
Bognar, A., Faivre, S., 2006: Geomorphological traces of the younger Pleistocene glaciation in the central part of the Velebit Mt, Hrvatski geografski glasnik 68(2), 19-30.

Casper, J. K., 2007: Water and Atmosphere: The lifeblood of natural systems, Infobase Publishing, London.

Chorowicz, J., Ichoku, C., Riazanoff, S., Kim, Y. J., Cervelle, B., 1992: A combined algorithm for automated drainage network extraction, Water Resources Research 28 (5), 1293-1302, DOI: 10.1029/91WR03098.

Čanjevac, I., 2012: Novije promjene protočnih režima u hrvatskom dijelu pori- ječja Dunava, Hrvatski geografski glasnik 74 (1), 61-74

Čanjevac, I., 2013: Tipologija protočnih režima rijeka u Hrvatskoj, Hrvatski geografski glasnik, 75(1), 23-42.

Eurogeographics Euroglobalmap, http://www. eurogeographics.org/products-and-services/euroglobalmap (25.08. 2017.).

European Environment Agency, dataset, https:// www.eea.europa.eu/data-and-maps/data/ wise-wfd-spatial (02. 08. 2017.).

European Environment Agency Glossary, https://www.eea.europa.eu/help/glossary/eea-glossary/drainage-basin (22. 08 . 2017.).
M. Pokupić

M. Varga

T. Bašić

Models of

geomorphometric

parameters and

drainage networks

for the territory

of the Republic of

Croatia

Modeli

geomorfometrijskih

parametara $\mathrm{i}$

drenažnih mreža za

prostor Republike

Hrvatske
Literature

Literatura 
HRVATSKI GEOGRAFSKI GLASNIK 80/1, 61-76 (2018.)
Faivre, S., 2008: Analyses of the Velebit Mountain ridge crests, Hrvatski geografski glasnik 69 (2), 21-39.

Farr, T. G., Rosen, P. A., Caro, E., Crippen, R., Duren, R., Hensley, S., ... Seal, D., 2007: The shuttle radar topography mission, Reviews of geophysics 45 (2), DOI: 10.1029/2005RG000183.

Freeman, T. G., 1991: Calculating catchment area with divergent flow based on a regular grid. Computers and Geosciences 17 (3), 413-422, DOI: 10.1016/00983004(91)90048-I.

Geokov, Slope in Topographic Maps, http:// geokov.com/education/slope-gradient-topographic.aspx, (21. 02. 2018.).

GRASS Development Team, 2017: Geographic Resources Analysis Support System (GRASS) Software, version 7.2, Open Source Geospatial Foundation. Electro, http://grass.osgeo.org, (21. 02. 2018.).

GRASS watershed, https://grass.osgeo.org/ grass75/manuals/r.watershed.html (14. 02 .2018.)

Hajam, R. A., Hamid, A., Bhat, S., 2013: Application of morphometric analysis for geo-hydrological studies using geo-spatial technology - A case study of Vishav Drainage Basin, Hydrology Current Research 4 (2), DOI: 10.4172/2157-7587.1000157.

Hengl, T., Reuter, H. I., 2008: Geomorphometry: Concepts, Software, Applications, Developments in Soil Science, vol. 33, Elsevier, Amsterdam.

Hunter, G. J., Goodchild, M. F., 1997: Modeling the uncertainty of slope and aspect estimates derived from spatial databases, Geographical Analysis 29 (1), 35-49, DOI: 10.1111/j.1538-4632.1997.tb00944.x.

Lušić D., Lušić D., 2011: Posebnosti krških područja u opskrbi vodom za piće, Hrvatska vodoprivreda 19 (194), 55-56.
Martz, L. W., Garbrecht, J., 1992: Numerical definition of drainage network and subcatchment areas from digital elevation models, Computers and Geosciences 18 (6), 747-761, 10.1016/0098-3004(92)90007-E.

Martz, L. W., Garbrecht, J., 1993: Automated extraction of drainage network and watershed data from digital elevation models, Journal of the American Water Resources Association 29 (6), 901-908, DOI: 10.1111/j.1752-1688.1993.tb03250.x.

Monde Geospatial, http://monde-geospatial. com/watershed-delineation-using-arc-hydro-tool-in-arcgis/ (14. 02. 2018.).

O'Callaghan, J. F., Mark, D. M., 1984: The extraction of drainage networks from digital elevation data, Computer vision, graphics, and image processing 28 (3), 323-344, DOI: 10.1016/S0734-189X(84)80011-0.

Olaya, V., 2009: Basic land-surface parameters, Developments in Soil Science 33, 141169.

Pahernik, M., Kereša D., 2007: Geomorphology Exploration Applies in Military Terrain Analyses-Index of Protective Potential Relief, Hrvatski geografski glasnik 69 (1), 41-56.

Pejnović, D., Radeljak Kaufmann, P., Lukić, A., 2017: The influence of cooperatives on the regional and rural development of Croatia, Hrvatski geografski glasnik 79 (2), 51-85.

Pike, R. J., Evans, I., Hengl, T., 2008: Geomorphometry: A Brief Guide, In: Hengl, T., Reuter, H.I. (Eds.): Geomorphometry Concepts, Software, Applications, Series Developments in Soil Science, vol. 33, Elsevier, Amsterdam, 3-33.

Sharma, H. S., 1981: Perspectives in geomorphology (Vol. 1), Concept Publishing Company, New-Delhi.

Shin, S., Paik, K., 2017: An improved meth- od for single flow direction calculation in grid digital elevation models, Hydrological Processes 31 (8), 1650-1661, DOI: 10.1002/hyp.11135.

Soille, P., Gratin, C., 1994: An efficient algorithm for drainage network extraction on DEMs, Journal of Visual Communication and Image Representation 5 (2), 181-189, DOI: 10.1006/jvci.1994.1017.

Tarboton, D. G., 1997: A new method for the determination of flow directions and upslope areas in grid digital elevation models, Water resources research 33 (2), 309-319, DOI: 10.1029/96WR03137.

Tarboton, D. G., Bras, R. L., Rodriguez-Iturbe, I., 1991: On the extraction of channel networks from digital elevation data, Hydrological processes 5 (1), 81100, DOI: 10.1002/hyp.3360050107.

USDA, 2010: Final Environmental Impact Statement Volume I, Norbeck Wildlife Project, United states Department of Agriculture.

Varga, M., Bašić, T., 2013: Quality Assessment and Comparison of Global Digital Elevation Models for Croatia, Cartography and Geoinformation 12 (20), 4-17.

Varga, M., Bašić, T., 2015: Accuracy validation and comparison of global digital elevation models over Croatia, International Journal of Remote Sensing 36 (1), 170-189, DOI: 10.1080/01431161.2014.994720.

Wilson, J. P., Aggett, G., Yongxin, D. E. N. G., 2008: Water in the landscape: a review of contemporary flow routing algorithms, in Advances in digital terrain analysis, 213236, Springer, Berlin, Heidelberg.

Wolock, D. M., McCabe, Jr. G. J., 1995: Comparison of single and multiple flow direction algorithms for computing topographic parameters in TOPMODEL, Water Resources Research 31 (5), 13151324, DOI: 10.1029/95WR00471.
Authors Autori

Marta Pokupić

mpokupic@geof.hr

univ. bacc. ing. geod. et geoinf., Faculty of Geodesy, University of Zagreb, Kačićeva 26 , 10000 Zagreb, Croatia

Matej Varga mvarga@geof.hr

PhD, mag. ing. geod. et geoinf., Faculty of Geodesy, University of Zagreb, Kačićeva 26 10000 Zagreb, Croatia

Tomislav Bašić tbasic@geof.hr PhD, Full Professor, dipl. ing. geod., Faculty of Geodesy, University of Zagreb, Kačićeva 26, 10000 Zagreb, Croatia 